\title{
Studies on the familial incidence and clinical history of patients with chronic unconjugated hyperbilirubinaemia
}

\author{
PAUL M. SMITH, J. E. MIDDLETON, AND ROGER WILliAMS \\ From Southampton General Hospital and King's College Hospital, London
}

EDITORIAL COMMENT Congenital unconjugated hyperbilirubinaemia represents in all probability a collection of conditions possibly of differing inheritance. Some forms may even be acquired. Certainly this paper suggests that these differences may exist and indicates that the degree of jaundice is very variable.

Chronic unconjugated hyperbilirubinaemia, occurring in the absence of other hepatocellular dysfunction or haemolysis, was first described as a familial disorder in 1902 by Gilbert and Lereboullet. However, in one recent textbook on genetics (Clarke, 1964) the method of inheritance is described as unknown, and the incidence of familial involvement varies widely in different studies. Alwall (1946) studied the relatives of 15 patients with an unconjugated hyperbilirubinaemia, and found that $26 \%$ of the parents and $55 \%$ of the siblings were similarly affected, whereas only $14 \%$ of another group of subjects gave a positive family history (Foulk, Butt, Owen, Whitcomb, and Mason, 1959). More recently Arias (1962) found that, while his severely affected patients appeared to suffer from the effects of an autosomal dominant gene with incomplete penetrance and varied expressivity, those with lower serum bilirubin levels conformed to no consistent genetic pattern.

In this paper we report the results of investigations in 11 patients with chronic unconjugated hyperbilirubinaemia and their families, with particular reference to the patterns of inheritance found and their relationship to the clinical onset and course.

\section{MATERIAL AND METHODS}

The 11 patients were initially investigated to exclude other causes of an unconjugated hyperbilirubinaemia. In addition to blood and reticulocyte counts, red cell survival was measured by the radio-chromium technique (Dacie and Lewis, 1963). In cases 1 and 2, the patients with the most marked jaundice, faecal urobilinogen excretion was estimated over a four-day collection period. Liver function tests done in all patients included measurement of the serum total and conjugated bilirubin
(MacLagen, 1951), serum glutamic oxaloacetic transaminase, alkaline phosphatase, serum albumin and globulin levels together with an electrophoretic strip. The 45-minute bromsulphthalein retention (after a dose of $5 \mathrm{mg} . / \mathrm{kg}$. body weight) was measured in two patients, and in nine of the 11 cases liver biopsy was performed. In four patients hepatic glucuronide formation was tested in vivo by estimating the urinary excretion of menthol glucuronide during a five-hour collection, after the ingestion of $1 \mathrm{~g}$. menthol orally (Arias, 1962).

\section{RESULTS}

The patients have been divided into three groups, according to the depth of jaundice and results of the family studies.

\section{GROUP I}

Family $A$ The propositus, a 14-year-old schoolboy, was first noticed to be jaundiced by a school master in October 1964, although according to his mother he had looked sallow since infancy. Otherwise he was well, and there were no abnormal findings on examination apart from jaundice. Serum total bilirubin levels over a two-month period ranged from 4.7 to $8.7 \mathrm{mg}$. $/ 100 \mathrm{ml}$., with conjugated bilirubin levels up to $1.1 \mathrm{mg} . / 100 \mathrm{ml}$. The other liver function tests, including bromsulphthalein excretion, were normal. Liver biopsy sections showed normal lobular architecture with no increase in pile pigment. Faecal urobilinogen excretion was $94 \mathrm{mg}$./24 hours (normal range $80-250 \mathrm{mg}$. $/ 24$ hours, Watson, Schwartz, Soborov, and Bertie, 1944). Menthol excretion was reduced, with $20.4 \%$ of the dose excreted in five hours, as compared with the normal range of 23.4 to $52.2 \%$ (Arias, 1962). The haemoglobin, reticulocyte count, red cell osmotic fragility, 
TABLE I

SUMMARY OF HISTORY AND MAJOR FINDINGS IN 11 PATIENTS WITH A CHRONIC UNCONJUGATED HYPERBILIRUBINAEMIA

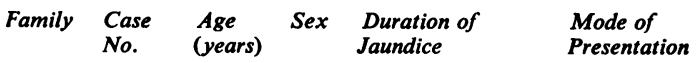

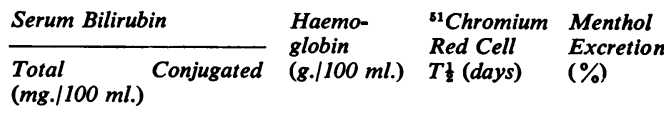

\begin{tabular}{|c|c|c|c|c|c|c|c|c|c|}
\hline \multicolumn{10}{|c|}{ Group I } \\
\hline $\mathbf{A}$ & 1 & 14 & $\mathbf{M}$ & $\begin{array}{l}2 \text { years (probably } \\
\text { since birth) }\end{array}$ & $\begin{array}{l}\text { School } \\
\text { examination }\end{array}$ & $6 \cdot 6$ & 0.9 & $15 \cdot 3$ & 28 \\
\hline B & 2 & 44 & $\mathbf{M}$ & Since birth & Noticed at birth & $15 \cdot 7$ & $1 \cdot 4$ & $17 \cdot 4$ & 27 \\
\hline \multicolumn{10}{|c|}{ Group II } \\
\hline C & 3 & 21 & $\mathbf{F}$ & $5-6$ years & Noticed by friend & $4 \cdot 2$ & $1 \cdot 0$ & $14 \cdot 0$ & 0 \\
\hline D & 4 & 21 & $\mathbf{M}$ & 6 years & $\begin{array}{l}\text { Nausea and } \\
\text { vomiting }\end{array}$ & $3 \cdot \overline{5}$ & 0.7 & 15.6 & 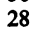 \\
\hline $\mathbf{E}$ & 5 & 18 & $\mathbf{M}$ & Since birth & $\begin{array}{l}\text { Routine } \\
\text { examination }\end{array}$ & $3 \cdot 0$ & 0.6 & $15 \cdot 4$ & 30 \\
\hline $\mathbf{F}$ & 6 & 19 & $\mathbf{M}$ & 2 years & Nausea & 2.5 & 0.5 & $16 \cdot 2$ & 29 \\
\hline \multicolumn{10}{|c|}{ Group III } \\
\hline $\mathbf{G}$ & 7 & 28 & $\mathbf{M}$ & 2 years & Abdominal pain & $2 \cdot 2$ & 0.6 & $14 \cdot 3$ & 27 \\
\hline $\mathbf{H}$ & 8 & 31 & $\mathbf{M}$ & 5 years & Peptic ulcer & 1.7 & 0.6 & 14.0 & 31 \\
\hline I & 9 & 22 & $\mathbf{F}$ & 1 year & Pyrexial illness & 1.6 & 0.7 & 13.9 & 27 \\
\hline $\mathbf{J}$ & 10 & 21 & $\mathbf{M}$ & 2 years & Abdominal pain & $1 \cdot 3$ & 0.7 & $14 \cdot 7$ & 26 \\
\hline $\mathbf{K}$ & 11 & 48 & $\mathbf{M}$ & 5 years & Gastrointestinal & 1.2 & 0.5 & $15 \cdot 2$ & 29 \\
\hline
\end{tabular}

red cell glucose 6-phosphate dehydrogenase activity, sternal marrow, and red cell survival were all normal (Table I).

There was no family history of jaundice, but examination showed that both parents and both siblings had raised unconjugated serum bilirubin levels (Fig. 1). All were well clinically, and other tests of liver function, including menthol excretion, were entirely normal, as were the haemoglobin and reticulocyte levels.

Family $B$ The propositus, aged 44 , had been jaundiced from the age of 2 weeks. At no time had the jaundice caused him any trouble, his development having been normal. His main symptoms were those of bronchiectasis, for which he had had several

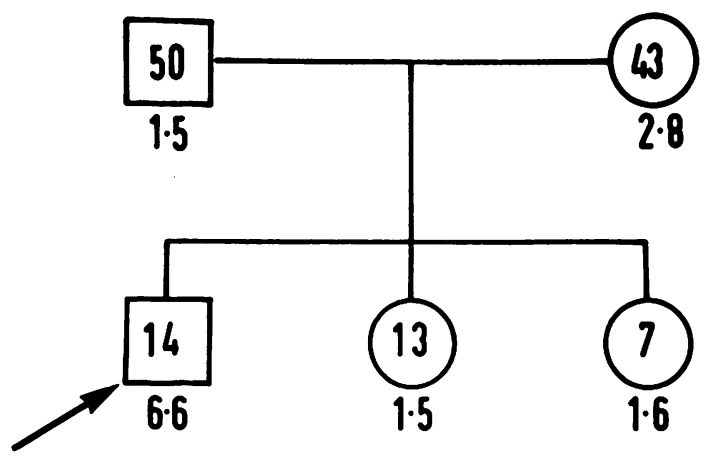

\section{FAMILY A}

FIG. 1. Family tree of case 1. Figures within symbols indicate age in years and those below the serum total bilirubin level in $\mathrm{mg} . / 100 \mathrm{ml}$. hospital admissions. The jaundice varied in intensity from time to time, and was worse during attacks of chest infection. He had previously been investigated in Sheffield, and serum total bilirubin levels between 1953 and 1956 ranged from 8.0 to $27.6 \mathrm{mg} . / 100 \mathrm{ml}$. During the past three years the level varied from 13.5 to $20.0 \mathrm{mg}$. $/ 100 \mathrm{ml}$., and the conjugated bilirubin fraction from 0.5 to $1.4 \mathrm{mg}$. $/ 100 \mathrm{ml}$. Other liver function tests had always been normal. When seen in 1966 there were no abnormal physical signs on examination apart from jaundice. Investigations confirmed that he had an unconjugated hyperbilirubinaemia, with a serum total bilirubin of $15.7 \mathrm{mg}$./ $100 \mathrm{ml}$., but otherwise he had normal liver function tests and a normal liver biopsy. Menthol excretion was also normal $(55.5 \%)$, but the faecal urobilinogen was slightly reduced at $50 \mathrm{mg}$. $/ 24$ hours. Red cell survival, with a ${ }^{51}$ chromium half-time of 24 days, was at the lower limit of the normal range (24-28 days), but there were no other signs of haemolysis, the haemoglobin level was normal, and the reticulocyte count was less than $1 \%$.

There was no family history of jaundice. His mother died from asthma, and his father from heart trouble at the age of 84 . One sister died at the age of 44 following an operation for a peptic ulcer. The only surviving sibling, a sister aged 58 , was examined and found to have a serum total bilirubin level of $0.5 \mathrm{mg} . / 100 \mathrm{ml}$.

\section{GROUP II}

Families $C-F$ The depth of jaundice was less, with serum total bilirubin levels of 2.5 to $4.2 \mathrm{mg}$./100 $\mathrm{ml}$. and conjugated bilirubin fractions from 0.5 to $1.0 \mathrm{mg} . / 100 \mathrm{ml}$. One patient (no. 3), a nurse, had 


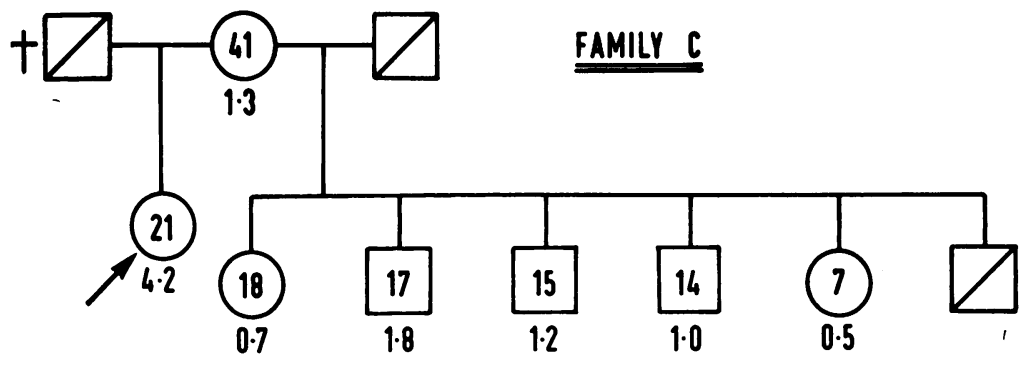

FIG. 2. Family tree of case 3. $\square$ indicates not tested.

been noticed to be jaundiced by a relative five years earlier, but, apart from occasional listlessness, was well. Another (no. 5), who was also asymptomatic, believed that he had been jaundiced since birth. The remaining two (nos. 4 and 6) had had bouts of nausea and vomiting, followed within 48 hours by the onset of jaundice, two years and six years ago respectively. This clinical picture had been diagnosed as infective hepatitis by the general practitioner in each case, but in neither instance did the onset or course of the illness appear typical. Only one patient (no. 5) thought that his jaundice was made worse by exertion or by illness. None had passed dark urine and pale stools at any stage.

Apart from the raised serum bilirubin levels all the liver function tests were normal. In case 4 the bromsulphthalein excretion at 30 minutes was $5 \%$. Menthol excretion was reduced $(16.2 \%)$ in the one patient (no. 3) in which it was measured. All had normal liver biopsies and haematological investigations, which included haemoglobin estimations, reticulocyte counts, and red cell survivals.

Fifteen of a total possible number of 18 parents and siblings were examined. Of these eight were found to have a raised serum bilirubin level, although

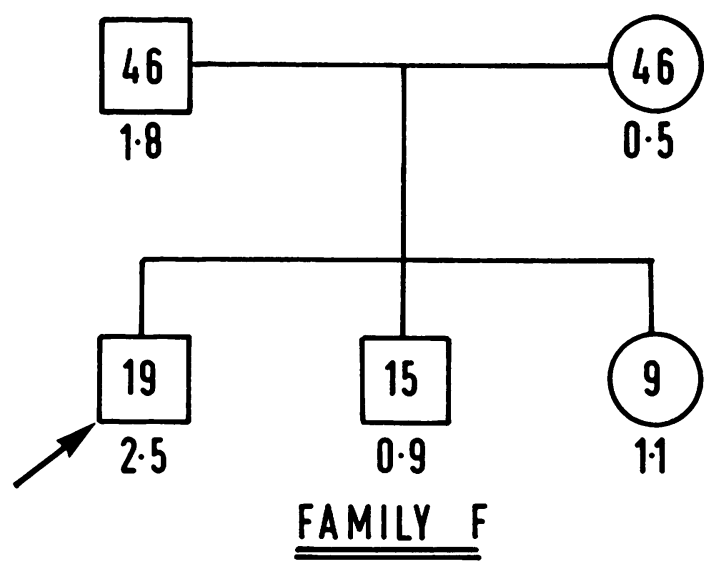

FIG. 3. Family tree of case 6 . none had complained of jaundice and all were well. Each patient in this group had at least one affected relative, either the father or mother, and approximately half the siblings examined, being involved. Family $\mathrm{C}$ is of particular interest (Fig. 2) in that the mother, who had a serum bilirubin level of $1.3 \mathrm{mg}$./ $100 \mathrm{ml}$., married twice, and by both husbands she had an affected child or children. In the other large family examined, that of case 6 , one sibling and one parent had a mild hyperbilirubinaemia (Fig. 3). The father of case 4 had a serum total bilirubin level of $1.2 \mathrm{mg} . / 100 \mathrm{ml}$., but the mother and the only sibling were unaffected. Case 5 was an only child; his mother had a serum total bilirubin of $1.2 \mathrm{mg}$./100 $\mathrm{ml}$., and the father a normal level. No relationship between the degree of the hyperbilirubinaemia and the age of the subject could be elicited.

\section{GROUP III}

Families $G-K$ The serum bilirubin values in the five propositi were lower than those of the previous group, with levels of 1.2 to $2.2 \mathrm{mg}$. $/ 100 \mathrm{ml}$. Three patients (nos. 7, 10, and 11) had noticed mild jaundice for the first time after bouts of abdominal pain, associated in one case with diarrhoea and vomiting. The remaining two patients had presented with a peptic ulcer and a pyrexial illness respectively; routine liver function tests showed the serum bilirubin levels to be slightly raised. In one (no. 7) a diagnosis of infective hepatitis had been made by the general practitioner, but this had not been confirmed by liver function tests, and there had been no initial anorexia. The patient thought that exertion made the jaundice worse, and attributed his symptoms of lassitude to it.

All liver function tests, with the exception of the serum bilirubin levels, were normal in this group, as were the haemoglobin levels, reticulocyte counts, and red cell survival times. In the four patients in whom a liver biopsy was performed, the histological appearances were normal.

We were able to examine seven parents and siblings out of a total number, living and dead, of 11, in four families. None had a raised serum bilirubin 
level. In the remaining family both parents were dead and the only sibling was not accessible.

\section{DISCUSSION}

Although the patients have been rather arbitrarily divided into three groups on the basis of the height of the serum bilirubin level and the pattern of familial involvement, this grouping may be of aetiological importance.

The two patients in group 1 are similar to those described by Arias (1962) with serum bilirubin levels of 6.4 to $19.9 \mathrm{mg} . / 100 \mathrm{ml}$., in whom he found evidence for partial reduction of hepatic glucuronyl transferase, both on enzyme assay and on diminished excretion of menthol. In the two patients described here menthol excretion was normal in one and only slightly reduced in the other. The significance of a reduced excretion is questionable, for the enzyme which conjugates menthol may be different from that responsible for bilirubin conjugation. According to Arias these patients differ from those with the Crigler-Najjar (1952) syndrome in that kernicterus is absent, the deficiency of glucuronyl transferase is partial and not complete, the condition is inherited as a Mendelian dominant and not as a recessive, and the serum bilirubin level is less than $20 \mathrm{mg} . / 100 \mathrm{ml}$. It is to be noted that a value of $27.6 \mathrm{mg}$. $/ 100 \mathrm{ml}$. was recorded on an earlier occasion in case 2 , and the distinction may not be quite so clear cut since Diamond and Schmid (1966) have recently reported a patient with the Crigler-Najjar syndrome in whom kernicterus developed at the age of 15 years.

It was not possible to elucidate the pattern of inheritance in family B, but in family A both parents and both siblings had raised unconjugated serum bilirubin levels. It may be postulated that in this family the parents are heterozygous for a dominant gene, their two mildly affected offspring being heterozygotes also, whereas their severely affected son has inherited two abnormal dominant genes. Alternatively, the gene could be described as being intermediate in type, the heterozygotes being only mildly jaundiced, with the full effects being manifested in the homozygous son.

The second group of patients had certain clinical similarities. Jaundice was present from birth in one, and in this patient and in one other the jaundice was noted in the absence of symptoms. For each patient in this group it was possible to find an affected relative, the pattern of inheritance suggesting that the disorder is transmitted as a dominant gene. This would agree with the findings of Alwall, Laurell, and Nilsby (1946), Manson (1928), and Dameshek and Singer (1941). It is difficult to determine the true incidence of familial involvement without measure- ment of the serum bilirubin level, and this probably accounts for the reported low incidence of $15 \%$ in 34 cases (Rozendaal, Comfort, and Snell, 1935) and $14 \%$ in 58 cases (Foulk et al., 1959).

The patients in group $\mathrm{C}$ had lower serum bilirubin levels than those in group B. None of them presented with symptomless jaundice alone. The age at which the diagnosis was made was also later than in group $B$, and no evidence of familial involvement could be found amongst the relatives tested. This does not necessarily exclude a genetic origin, for Billing, Williams, and Richards (1964) were able to show an impairment in the handling of unconjugated bilirubin following an intravenous load in a relative with a serum bilirubin level of only $0.4 \mathrm{mg} . / 100 \mathrm{ml}$. However, it is possible that the patients in group $\mathrm{C}$ owe their hyperbilirubinaemia not to a genetic but to an acquired cause. Levine and Klatskin (1964) found evidence of another illness in all but 33 of 366 cases of mild unconjugated hyperbilirubinaemia. None of the patients in this group, or in group B, who had had nausea and vomiting on occasion, and in whom a diagnosis of infective hepatitis had been made by the general practitioner, was the onset typical on careful questioning, and in neither group was an abnormal liver biopsy obtained. True posthepatitis hyperbilirubinaemia is probably much rarer than previously supposed, but difficulties will continue to arise because patients with chronic unconjugated hyperbilirubinaemia may become more jaundiced during infections, and at such times often have symptoms of nausea and vomiting.

Another problem arises in the differentiation of such cases from patients with a compensated haemolytic state. The patients described by Arias (1962) as having compensated haemolytic disease had only slightly reduced ${ }^{51}$ chromium red cell half times (19-23 days), and this degree of haemolysis is insufficient to cause jaundice in the absence of an impaired capacity of the liver to remove bilirubin. In addition, some reduction in red cell survival occurs in many different varieties of jaundice (Pitcher and Williams, 1963). In no case in the series reported here was red cell survival shortened, although in case 2, the patient with the highest bilirubin level, it was at the lower limit of normal.

It is of interest in relation to the possible presence of a congenital defect that the commonest age of detection was in the middle teens in group $\mathrm{B}$, and in the twenties for group C. In the series reported by Foulk et al. (1959) the mean age at which jaundice was noticed was 18 . Of the 11 patients reported here, nine were male and only two female, but male and female relatives were equally affected, and Dameshek and Singer (1941) failed to find any sex linkage in their series. It is clear also that the degree of eleva- 
tion in serum bilirubin level observed in groups B and $\mathrm{C}$ must represent only a partial defect in the handling of unconjugated bilirubin by the liver. Further understanding of the aetiology of this group of conditions must await the development of better methods for quantitation of the processes responsible for the uptake and conjugation of bilirubin by the liver.

\section{SUMMARY}

Eleven patients with chronic unconjugated hyperbilirubinaemia and 27 close relatives were investigated and separated into three groups. The first consisted of two patients with serum total bilirubin levels of 6.6 and $15.7 \mathrm{mg} . / 100 \mathrm{ml}$. respectively. Neither had symptoms apart from the jaundice. The findings in the family of the first case suggested that he was homozygous for the causative gene, as both parents and the two siblings examined were mildly affected.

The second group contained four patients whose serum total bilirubin levels ranged from 2.5 to $4.2 \mathrm{mg}$. $/ 100 \mathrm{ml}$., and in whom examination of the families showed a pattern of dominant transmission. The five patients in the third group had lower serum total bilirubin levels, and the cause of the jaundice was uncertain. No involvement of the relatives could be detected.

Several patients in the second and the third groups complained of nausea, vomiting, and abdominal pain at the time that the jaundice was first noticed, but in no instance was the onset or the subsequent findings typical of infective hepatitis.

We wish to thank Dr. A. K. Miller for referring case 2, Mr. D. Anderson and Dr. R. D. Hyde for performing the red cell survival studies, and Dr. R. A. Goodbody for the histological reports.

Requests for reprints should be sent to R. W., King's College Hospital, London, S.E.5.

\section{REFERENCES}

Alwall, N. (1946). On hereditary, non-hemolytic bilirubinemia. Acta med. scand., 123, 560-595.

- Laurell, C. B., and Nilsby, I. (1946). Studies on heredity in cases of 'non-hemolytic bilirubinemia without direct van den Bergh reaction' (hereditary, non-hemolytic bilirubinemia). Ibid., 124, 114-125.

Arias, I. M. (1962). Chronic unconjugated hyperbilirubinemia without overt signs of hemolysis in adolescents and adults. J. clin. Invest., 41, 2233-2245.

Billing, B. H., Williams, R., and Richards, T. G. (1964). Defects in hepatic transport of bilirubin in congenital hyperbilirubinaemia : an analysis of plasma bilirubin disappearance curves. Clin. Sci., 27, 245-257.

Childs, B., and Najjar, V. A. (1956). Familial nonhemolytic jaundice with kernicterus. Pediatrics, 18, 369-377.

Clarke, C. A. (1964). Genetics for the Clinician, 2nd ed. Blackwell, Oxford.

Crigler, J. F., Jr., and Najjar, V. A. (1952). Congenital familial nonhemolytic jaundice with kernicterus. Pediatrics, 10, 169-180.

Dacie, J. V., and Lewis, S. M. (1963). Practical Haematology, 3rd ed. Churchill, London.

Dameshek, W., and Singer, K. (1941). Familial nonhemolytic jaundice. Constitutional hepatic dysfunction with indirect van den Bergh reaction. Arch. intern. Med., 67, 259-285.

Diamond, I., and Schmid, R. (1966). Experimental bilirubin encephalopathy. The mode of entry of bilirubin-14C into the central nervous system. J. clin. Invest., 45, 678-689.

Foulk, W. R., Butt, H. R., Owen, C. A., Jr., Whitcomb, F. F., Jr., and Mason, H. L. (1959). Constitutional hepatic dysfunction (Gilbert's disease): its natural history and related syndromes. Medicine (Baltimore), 38, 25-46.

Gilbert, A., and Lereboullet, P. (1902). La cholémie simple familiale. Gaz. hebd. Méd Chir., 49, 889-897.

Levine, R. A., and Klatskin, G. (1964). Unconjugated hyperbilirubinemia in the absence of overt hemolysis. Amer. J. Med., 36, 541-552.

MacLagen, N. F. (1951). Liver function tests. In Recent Advances in Clinical Pathology, 2nd ed., pp. 149-169, edited by S. C. Dyke. Churchill, London.

Manson, J. S. (1928). Hereditary icterus, or familial acholuric jaundice. Brit. med. J., 1, 131-132.

Pitcher, C. S., and Williams, R. (1963). Reduced red cell survival in jaundice and its relation to abnormal glutathione metabolism. Clin. Sci., 24, 239-252.

Rozendaal, H. M., Comfort, M. W., and Snell, A. M. (1935). Slight and latent jaundice: significance of elevated concentrations of bilirubin giving indirect van den Bergh reaction. J. Amer. med. Ass., 104, 374-379.

Watson, C. J., Schwartz, S., Soborov, V., and Bertie, E. (1944). Studies of urobilinogen. V. A simple method for the quantitative recording of the Ehrlich reaction as carried out with urine and feces. Amer. J. clin. Path., 14, 605-615. 